\title{
Sources, spatial distribution and abundance of marine debris on Thondi coast, Palk Bay, Southeast coast of India
}

Karthikeyan Perumal ( $\nabla$ pkarthikeyangold@gmail.com )

Alagappa University https://orcid.org/0000-0002-8782-4146

Vishwanath Boopathi

Alagappa University

Stella Chelladurai

Alagappa University

Subagunasekar Muthuramalingam

Saveetha Institute of Medical and Technical Sciences: Saveetha University

Prakash Raja

Pondicherry University

\section{Research Article}

Keywords: Marine debris, clean - coast index, plastics, waste management, beach, Thondi coast

Posted Date: June 16th, 2021

DOl: https://doi.org/10.21203/rs.3.rs-625168/v1

License: (9) This work is licensed under a Creative Commons Attribution 4.0 International License. Read Full License

Version of Record: A version of this preprint was published at Environmental Sciences Europe on December 1st, 2021. See the published version at https://doi.org/10.1186/s12302-021-00576-x. 


\section{Abstract}

Background: The Thondi coast is a rich source of valuable natural marine resources, as well as many socioeconomically significant activities like agriculture, aquaculture, and fishing. The area receives an excess of untreated solid and liquid waste as a result of these activities. The study focus on the abundance, distribution, and status of the Clean - Coast Index (CCl) of marine debris from the Thondi coast, Palk Bay, Southeast coast of India. This research was the first to assess the type and quantity of marine debris on the Thondi coast.

Results: A total of 1636 marine debris items $/ \mathrm{m}^{2}$ and 4.09 density of the items $/ \mathrm{m}^{2}$ were determined in the marine debris: plastics $(77.49 \%)$, cotton swabs $(8.62 \%)$, cigarette butts $(10.15 \%)$, and food containers (3.73\%). From the result, the $\mathrm{CCl}$ is ranged between 4.25 (clean) and 20.4 (extremely dirty) with a mean of 8.92 (moderate) in the Thondi coast assessed.

Conclusion: These studies were conducted for the first time in this region. Finally, the high CCI value of 20.4 in the coast indicates that the marine debris pollution levels are high at the time of sampling in the middle part of the Thondi coast (most of the beach is covered with plastic) due to land - based marine debris (62.45\%), sea - originated marine debris (21.14\%) and unknown sources (16.41\%) of the items. Our findings serve as a baseline for potential evaluations of marine environments. Input prevention should be the goal of management efforts, which include proper waste management, plastic recycling, and stringent penalties for illegal waste dumping.

\section{Background}

Marine debris (solid waste), marine litter (discarded man-made), and microplastics are affects and threatens marine life, hinder navigation safety, and throws human health at risk [1]. Our oceans and rivers are clogged with a range of aquatic waste, from soda cans and plastic bags to discard fishing gear and ships. Along with other major environmental problems such as climate change, ocean acidification, and biodiversity depletion, marine debris has been described as a global concern [2]. It is considered one of the most serious issues facing the marine ecosystem, as well as a major threat to biodiversity. This problem now affects every country on the planet. Storm drains and sewers, as well as shoreline and outdoor events like picnicking and beach-going, contribute to the bulk of the garbage and debris that litter our beaches. Abandoned or discarded fishing gear is also a major issue, as it can entangle, kill, maim, and drown marine animals, as well as cause property harm. Since the 1950s, plastic production has increased at an exponential pace, which is expected to continue in the coming decades. In a recent study, the annual amount of plastic waste entering the marine environment from land approaches 4.8 million tons (Mt), with the potential to reach $12.7 \mathrm{Mt}$. Plastic waste is rapidly entering the ocean, with cumulative inputs of plastic waste to the ocean possibly exceeding $250 \mathrm{Mt}$ by 2025. In 2010, India had a total of 187.47 million tons of mismanaged plastic waste and a coastal population of 6 million people. In India, $0.01 \mathrm{~kg}$ per person per day was consumed by Indians in 2010 [3]. 
Marine debris is a global issue that has been investigated in a number of areas [4, 5]. It can be found in all marine environments, from beaches to the farthest reaches of the oceans [6]. Plastic, paper/cardboard, wood textile, metal, fabric, glass, rubber, fishing gear, and e-waste are all found in the ocean [7-9] with plastics being the most dominant portion [10-12]. The marine debris (plastic) were classified as microplastics $(<5 \mathrm{~mm})$, mesoplastics $(>5 \mathrm{~mm})$, or macroplastics $(>25 \mathrm{~mm}$ ) based on the size ranges [1, 13-16].

[17] was developed and is suggested as a new tool for determining coast cleanliness. Many researchers were studied CCl using in worldwide regions in Mkomani beach [18], Kenya; in Cyprus [19]; in the Red Sea, Eritrea [20]; in Qatar [21]; in Dungonab and Mukkawar Island, Sudan, Red Sea [22]; in Asparuhovo Beach, Varna, Bulgaria [23]; in Beach off southwestern Luzon, Philippines [24]; in Pelagos sanctuary (The Ligurian Sea - NW Mediterranean Sea [25]; in Beaches of Arraial do Cabo, RJ, Brazil [26]; in Eastern Mediterranean [27]; in Salvador, Brazil [28]; in North-western Adriatic beaches [10]; in Slovenia [30]; and in Israeli coast [17]. The objective of this study is to identify the sources, spatial distribution, and abundance of marine debris along the Thondi coast, Palk Bay, Southeast coast of India, and to explore possible sources of marine debris, so as to come up with the preferences for enhanced future marine debris management in India.

\section{Description of the study area}

Thondi $\left(9^{\circ} 43 \llbracket 26 \varangle \mathrm{N}\right.$ and $\left.79^{\circ} 02 \rrbracket 55 \bigotimes \mathrm{E}\right)$ is located in the Palk Bay, Tamil Nadu, Southeast coast of India (Fig. 1). The study area serves as a treasure of various economically important marine resources, many socioeconomic important activities such as agriculture, aquaculture, and fishing. Due to these activities the area receives an abundance of untreated solids and liquid waste. The study area is mostly occupied by agriculture land (75\%), built-up land (5\%), wastelands (7\%), and water bodies $(13 \%)$. Fishing is a very important economic activity carried out in Thondi. It is also a major source of pollution as well as a threat to some of the marine species, especially to Sea Urchins, Star fishes, Lambis lambis due to the by catch of these species by fisherman. Oil and pain used in the boats is the primary pollutants along with plastics, ghost nets etc. The area is rich in valuable marine algae such as the marine brown algae, red algae, and green algae.

The Palk Bay area is known for its rich marine biodiversity and resources such as sea grass, shrimps, seaweed, lobsters, mollusks, coelenterates, crabs, shellfish, squids, and finfish. Crab exports are the economic backbone of Thondi. Sea grass plays a vital role in the production of commercially valuable fishes in this region as it provides food and shelter for various marine organisms and is involved in recycling of nutrients. Thondi is not just an economically important coast, but it is also an ecologically important coast. It houses many endangered species like sea anemones, sea cucumber, along with sea horses, sea urchins, sponges, fishing and lack of knowledge is causing serious destruction to the population of this species. Due to an abundance of sea grass Thondi was once the home of endangered Dugong, but due to hunting for meat Dugong population has faced extreme decline. The region generally receives rainfall from south, west and northeast monsoons. The shore water has an average depth of 1-2 
$\mathrm{m}$ and the sea water is rich in nutrients with moderately high turbidity. The wave action is minimal and the sediments are muddy [33]. Except for the ones carried out in the sense of this report, there are no formal beach cleanup activities carried out on the Thondi coast.

\section{Materials And Methods}

\section{Marine debris collection}

All studies performed based on the guideline NOAA Marine Debris Program [16]. At each coast, ten transects measuring $200 \mathrm{~m} \times 2 \mathrm{~m}$ of the shoreline identified, counted, and recorded using by [16]. The marine debris was collected from Thondi shoreline and conducted in March 2021 during low tide. The precise position of each location was marked out using GPS. The sample collection was done by field assistants during the survey, which took place during low tidal periods. For the abundance of beach macro-debris greater than $2.5 \mathrm{~cm}$, the longest dimension of each type of debris was measured (macrodebris). The study has included smaller mesodebris particles $(0.5-2.5 \mathrm{~cm})$, such as cigarette butts. After sorting the debris into types, the contents of each transect were stored in separate bin bags. The debris was then returned to the laboratory and rinsed with pipe water to remove any soil or sand that could cause inaccuracy during the weighing process. Before being weighed, the debris was air-dried in the lab and identified separately. The marine debris was listed as plastic, plastic stirrers, straws, plastic silverware, cotton swabs, plastic cling wrap, cigarette butts, plastic reseal able bags, and food containers based on the labeled given by [31].

\section{Density of marine debris}

The density of marine debris (items $/ \mathrm{m}^{2}$ ) per transect was determined [32] as follows:

$$
C=\frac{n}{(a \times b)}
$$

Where, the density (C) of items will be calculated as the number of items $\mathrm{m}^{2}, \mathrm{n}=$ total number of marine debris items per transect, and $a$ - width $(\mathrm{m})$ and $b$ - length $(\mathrm{m})$ of the transect. In different coastal regions, many researchers followed and successfully analyzed [6, 18, 33-35].

\section{Clean-coast Index (CCI)}

Clean - Coast Index $(\mathrm{CCl})$ is being used to measure the cleanliness of the coast [17]. The CCl, which classifies beaches based on the amount of marine debris found on them, is expressed as follows:

$$
\mathrm{CCI}=\frac{\mathrm{X}}{\mathrm{Y}} \times K
$$

Where, $X$ is total plastic in parts on transect; $Y$ is total area of transect; $K$ is constant (20 involved in the equation). The $\mathrm{CCl}$ values, grade, and visual assessment are given in table 1 . The following authors were 
successfully completed in the $\mathrm{CCl}$ in various coastal regions [10, 17-28].

\section{Source identification}

To classify the origins of marine debris along the coast, the Matrix Scoring Technique (MST) is used [36]. The source of marine debris is classified as land or river, sea, or unknown. Land-based causes include recreational use of the shore, public littering, agricultural activities, and sewage-related debris [37]. Sea waste may be carried to the sea by rivers, industrial discharges, runoffs, and waves. The debris from commercial shipping, fishing and boating activities (traps, fishing nets, and buoys), and fish market sites that has drifted to the shore from the sea is the source of the sea-based sources. Unknown sources may be found on land or at sea, with no labels indicating where they came from [33]. All of those classifications were used to classify the sources in this article.

\section{GIS analysis}

The spatial distribution of marine debris in the study area was determined using the inverse distance weighted (IDW) method and ArcGIS 10.2 software.

\section{Results}

\section{Density and spatial distribution of marine debris}

The distribution, density, and Clean-Coast Index (CCl) of the debris in this study were measured at ten separate locations along the study region (Table 2 and Fig. 2). The result of spatial distribution of pollution status of $\mathrm{CCl}$ in the study area is shown in the fig. 3. In result of a total debris distribution of $124,153,176,132,113$, and 129 items $/ \mathrm{m}^{2}$ with a density of $0.31,0.38,0.44,0.33,0.28$, and 0.32 items $/ \mathrm{m}^{2}$ and the calculated $\mathrm{CCl}$ values is $6.2,7.65,8.8,6.6,5.65$, and 6.45 which indicates moderate pollution in the locations $1,2,3,5,7$, and 9 respectively. Total debris of 85 , and 93 items $/ \mathrm{m}^{2}$ with a density of 0.21 , and 0.23 items $/ \mathrm{m}^{2}$ and the calculated $\mathrm{CCl}$ values is 4.25 , and 4.65 which indicates clean in the locations 4 , and 8 respectively. In Location 6 , total debris of $407 \mathrm{items} / \mathrm{m}^{2}$ with a density of 1.02 items $/ \mathrm{m}^{2}$ and the calculated $\mathrm{CCl}$ values is 20.4 which indicates extremely dirty; and location 10 , total debris of 224 items $/ \mathrm{m}^{2}$ with a density of 0.56 items $/ \mathrm{m}^{2}$ and the calculated CCl values is 11.2 which indicates dirty. Total debris of 224 items $/ \mathrm{m}^{2}$ with a density of $0.56 \mathrm{items} / \mathrm{m}^{2}$ and the calculated $\mathrm{CCl}$ values is 11.2 which indicates dirty. In this study, a total of 1,636 items $/ \mathrm{m}^{2}$ was observed in the all locations, 1268 of which were plastic (Table 2) in ten transect. The debris densities during the ten locations ranged between 0.21 and 1.02 items $/ \mathrm{m}^{2}$ with a mean of $0.408 \mathrm{items} / \mathrm{m}^{2}$ in the Thondi coast (Table 2).

In the present study, clean coast index is ranged between 4.25 (Clean) and 20.4 (Extremely dirty) with a mean of 8.92 (moderate) in the Thondi Coast. We find the study area is mostly moderate in the result of $\mathrm{CCl}$ in the Thondi coast, Palk Bay of Southeast India. The distribution of debris identified in the study area 
are plastic bottles, plastic bags, cigarette butts, plastic cling wrap, plastic cups, fishing net, cotton swabs, plastic silverware, straws, plastic stirrers, and food containers. In this baseline study described that Thondi coast is moderate (60\%) be identified. In previous studies and the results, the values of the $\mathrm{CCl}$ are compared to those of the International region is shown in table 3. In present study, the calculated $\mathrm{CCl}$ values is concentration of $6.2,7.65,8.8,6.6,5.65$, and 6.45 which indicates moderate pollution in the locations $1,2,3,5,7$, and 9 respectively.

\section{Discussion}

The $\mathrm{CCl}$ represents that the locations $1,2,3,5,7$, and 9 which indicates visual assessment of a few pieces of debris can be detected. Similarly, [23] reported marine debris concentration of $0.42 \mathrm{items} / \mathrm{m}^{2}$ at Asparuhov beach, Varna in Bulgaria. The debris identified are plastic cups, and industrial packaging. The beach is categorized as moderate by $\mathrm{CCl} ;$ [26] suggested that marine debris concentration of 6.06 units $/ \mathrm{m}^{2}$ at the beach of Arrial do cabo in Rio De Jeniro, Brazil. The debris in the study area is identified as food packages, straw, bottle caps, disposal cups, swab rod, light stick, and bottle. According to $\mathrm{CCl}$ the beach Prainha is categorized as dirty to moderate, Pontal beach is categorized as dirty and grand beach is categorized as clean to moderate, and [20] explained that marine debris abundance of 0.1-0.35 items $/ \mathrm{m}^{2}$ in red sea, Eritera. The marine debris identified are cloths, foamed plastics, and plastics. Red sea (Eritera) is determined as very clean - moderate by $\mathrm{CCl}$.

At locations 4 , and $8(4.25,4.65$ values indicates clean by $\mathrm{CCl}$ which indicate no debris is seen over a large area in the locations. In similarly, [19] reported marine debris abundance of 9.3 items $/ \mathrm{m}^{2}$ in Cyprus. The marine debris identified are PP and PE. The Cyprus beach is categorized as clean by $\mathrm{CCl}$, and [17] identified plastic debris along Isreal coast and according to clean-coast index the coast is classified as clean; and [10] reported marine debris concentration of 0.2 litter item $/ \mathrm{m}^{2}$ in NW Adriatic beaches. The debris is identified as cigarette butts, unrecognizable plastic pieces, bottle caps. The beaches are categorized as clean-dirty according to $\mathrm{CCl}$. At similar reported, [18] reported that marine debris abundances of 0.042 items $/ \mathrm{m}^{2}$ in the Mkomani beach, Kenya. The marine debris identified are food products packaging, $\mathrm{PC}, \mathrm{HP}, \mathrm{PET}, \mathrm{SL}, \mathrm{HDPE}, \mathrm{PP}$, and PVC. In the Mkomani beach is determined extremely dirty by $\mathrm{CCl}$.

[21] reported marine debris concentration of 1.98 items $/ \mathrm{m}^{2}$ in Qatar and the debris are identified as plastics, metal, glass, paper, fabric, rubber, and processed food \& Qatar beach is identified as dirty to extremely dirty by $\mathrm{CCl}$. [25] studied that marine debris concentration of 34,027 items $/ \mathrm{m}^{2}$ at Pelagos sanctuary (Ligurian Sea - NW Mediterranean Sea). The debris is identified as glass, rubbers, textiles, foam/sponge, plastic, and PS. The Ligurian sea is categorized as very clean-extremely dirty by $\mathrm{CCl}$. [27] researched that marine debris of 3305 items $/ \mathrm{m}^{2}$ in eastern Mediterranean. The debris are indentified as foam, cloth, glass, metal, papers, rubber, and wood. The Eastern Mediterranean is categorized as very clean-extremely dirty by CCI. [29] reported that the marine debris concentration of 1.51 items $/ \mathrm{m}^{2}$ in Slovenia. The debris are identified as fishing ropes, cutlery, lolly sticks, cups, drink bottles, cosmetics 
packaging, string, caps and lids, fishing net floats, foam, and drink bottles. The area is categorized as extremely dirty by $\mathrm{CCl}$. The estimated $\mathrm{CCl}$ value for position 10 is 11.2 (dirty), indicating that there is a lot of debris on the beach. Likewise [22] reported that the marine debris concentration of $506.2 \mathrm{items} / \mathrm{m}^{2}$ at Sudan, Red sea. The debris are identified as plastics, textiles, fishing gears, metals, and wood, glass, food, and wrappers/packs. The beach is categorized as very clean-dirty by CCI. [24] studied that marine debris concentration of 0.26 items/gram at the beach of southwestern Luzon in Philippines. The debris are identified as plastic bags, disposable cup and a sachet. The beach is categorized as dirty by $\mathrm{CCI}$. [28] explained that marine debris of concentration 50.82 items $/ \mathrm{m}^{2}$ in Salvodar, Brazil. The debris is identified as plastic, metal, glass, wood, cloth, plastic bags, beverage cans, barbecue and wooden sticks and plastic fragments. The area is categorized as dirty by $\mathrm{CCl}$.

\section{Sources of marine debris}

The three main categories of sources that contribute to the marine debris input along the Thondi coast are land-based, sea-based, and unknown sources. According to the findings of the study, litter from landbased sources contributes the most to the total amount of litter generated. Overall, the land - based marine debris reported for $62.45 \%$ of the items, sea - originated marine debris examined for $21.14 \%$ items, and marine debris $16.41 \%$ items could not be identified. Similarly [21] reported that $45.3 \%$ of the items account for land-based marine litter, $8.75 \%$ of the items represent sea-originated marine litter and $25.4 \%$ of the items could not be identified in the west coast of Qatar. Any man-made product that has ended up in the marine environment after being lost or dumped at sea or on land is referred to as marine litter. A few litter floats in the oceans, some washes up on our shores, but the majority settles on the seafloor. Unprocessed waste from sewage treatment facilities, products washed down rivers, and discarded fishing boats are all sources of marine debris. Plastic bottles drink containers, cigarette butts, and microplastics are examples of marine debris.

\section{Conclusions}

Studies were carried out for the first time at the Thondi coast in March 2021. In concluding that, the high $\mathrm{CCl}$ values of 20.4 are indicated extremely dirty (most of the beach is covered with plastic) in the coast indicates that the marine debris contamination levels are high at the time of sampling in the middle part of Thondi coast. The main sources of marine debris pollution identified are land and sea - based, and unknown sources in the study area. Even more research should be conducted to determine which plastic forms are most prevalent in the Thondi coastal and marine environments. The Thondi coast has been polluted by plastic marine debris, especially plastic bags and food packaging, according to this report. Improved waste disposal infrastructure is urgently needed in coastal areas, especially along the Thondi coast, as well as citizen outreach projects to raise public awareness about plastic debris. This research has drawbacks in that it only offers a snapshot of recently accumulated marine debris particles on beaches. Finally, potential measures to combat plastic waste in the country can be drafted, such as reducing the production and usage of plastic (sachet) packaging and/or seeking alternatives. 


\section{List Of Abbreviations}

CCI: Clean - Coast Index; Mt: million tons; NOAA: National Oceanic and Atmospheric Administration; MST: Matrix Scoring Technique; IDW: Inverse Distance Weighted; PC: Personal Care products; HP: Household Products; PET: Polyethylene Terephthalate; SL: Single-Layered; HDPE: High-Density Polyethylene: PP: Polypropylene; PE: Polyethylene; PS: Polystyrene; PVC: Polyvinyl Chloride.

\section{Declarations}

\section{Acknowledgement}

The authors are grateful to thank the Head of the Department, School of Marie Sciences, Department of Oceanography and Coastal Area Studies, Alagappa University, Karaikudi- 630003.

\section{Authors' contributions}

Karthikeyan Perumal: conceptualization, supervision, investigation, methodology, writing - original draft, writing - review \& editing; Vishwanath Boopathi: data curation, formal analysis;

Subagunasekar Muthuramalingam: software; data analysis; investigation; Prakash Raja: software; data analysis; investigation.

\section{Funding}

No funding

Availability of data and material

http://doi: 10.17632/dmxsk2mjz6.2

\section{Declarations}

\section{Ethics approval and consent to participate}

Not applicable

Consent for publication

Not applicable

\section{Competing Interest}

The authors declare that they have no competing interests.

\section{Author details}


${ }^{1}$ School of Marine Sciences, Department of Oceanography and Coastal Area Studies, Alagappa University, Karaikudi - 630 003, Tamil Nadu, India

${ }^{2}$ Department of Civil Engineering, Saveetha School of Engineering, Saveetha Institute of Medical \& Technical Sciences, Chennai - 602105, Tamil Nadu, India

${ }^{3}$ Department of Earth Sciences, Pondicherry University, Puducherry - 605 014, India

\section{References}

1. Cheshire AC, Adler E, Barbiere J, Cohen Y, Evans S, Jarayabhand S, Jeftic L, Jung RT, Kinsey S, Kusui, ET, Lavine I, Manyara P, Oosterbaan L, Pereira MA, Sheavly S, Tkalin A, Varadarajan S, Wenneker B, Westphalen G (2009) UNEP/IOC Guidelines on Survey and Monitoring of Marine Litter. UNEP Regional Seas Reports and Studies, No. 186; IOC Technical Series No. 83: 120. http://hdl.handle.net/20.500.11822/13604

2. Sutherland WJ, Bardsley S, Bennun L, Clout M, Cote IM, Depledge MH, Fleishman E (2011) Horizon scan of global conservation issues for 2011. Trends Ecol Evol. 26(1), 1016. https://doi:10.1016/j.tree.2010.11.002

3. Jambeck JR, Geyer R, Wilcox C, Siegler TR, Perryman M, Andrady A, Law KL (2015) Plastic waste inputs from land into the ocean. Science. 347(6223), 768-771. https://doi:

10.1126/science. 1260352

4. Portman ME, Pasternak G, Yotam Y, Nusbaum R, Behar D (2019) Beachgoer participation in prevention of marine litter: Using design for behavior change. Mar Pollut Bull. 144, 110. https://doi:10.1016/j.marpolbul.2019.04.071

5. Schernewski G, Balciunas A, Grawe D, Grawe U, Klesse K, Schulz M, Werner S (2017) Beach macrolitter monitoring on southern Baltic beaches: results, experiences and recommendations. J Coast Conserv. 22 (1), 5-25. https://doi:10.1007/s11852-016-0489-x

6. Pham CK, Ramirez LE, Alt CHS, Amaro T, Bergmann M, Canals M, Company JB, Davies J, Duineveld, G, Galgani F, Howell KL, Huvenne VAI, Isidro E, Jones DOB, Lastras G, Morato T, Pereira JNG, Purser A, Stewart H, Tojeira I, Tubau X, Rooij DV, Tyler PA (2014) Marine Litter distribution and density in European Seas, from the Shelves to Deep Basins. PLoS ONE 9(4):

e95839. https://doi.org/10.1371/journal.pone.0095839

7. Duhec AV, Jeanne RF, Maximenko N, Hafner J (2015) Composition and potential origin of marine debris stranded in the Western Indian Ocean on remote Alphonse Island. Seychelles. Mar Pollut Bull. 96, 76-86. https://doi: 10.1016/j.marpolbul.2015.05.042

8. Neves D, Sobral P, Ferreira JL, Pereira T (2015) Ingestion of microplastics by commercial fish off the Portuguese coast. Mar Pollut Bull. 101 (1), 119-126. https://doi:10.1016/j.marpolbul.2015.11.008

9. Strafella P, Fabi G, Spagnolo A, Grati F, Polidori P, Punzo E, Scarcella G (2015) Spatial pattern and weight of seabed marine litter in the northern and central Adriatic Sea. Mar Pollut Bull. 91(1), 120- 
127. https://doi:10.1016/j.marpolbul.2014.12.018

10. Munari C, Corbau C, Simeoni U, Mistri M (2016) Marine litter on Mediterranean shores: Analysis of composition, spatial distribution and sources in north-western Adriatic beaches. Waste Manag. 49, 483-490. https://doi:10.1016/j.wasman.2015.12.010

11. Okuku EO, Kiteresi LI, Owato G, Mwalugha C, Omire J, Mbuche M, Brenda G (2020a) Baseline mesolitter pollution in selected coastal beaches of Kenya: Where do we concentrate our intervention efforts? Mar. Pollut. Bull. 158, 111420. https://doi:10.1016/j.marpolbul.2020.111420

12. Okuku EO, Kiteresi LI, Owato G, Otieno K, Mwalugha C, Mbuche M, Omire J (2020b) The impacts of COVID-19 pandemic on marine litter pollution along the Kenyan Coast: A synthesis after 100 days following the first reported case in Kenya. Mar Pollut Bull.

111840. https://doi:10.1016/j.marpolbul.2020.111840

13. Andrady AL (2011) Microplastics in the marine environment. Mar. Pollut. Bull. 62, 15961605. https://doi.org/10.1016/j.marpolbul.2011.05.030

14. Cole M, Lindeque P, Halsband C, Galloway TS (2011) Microplastics as contaminants in the marine environment: a review. Mar Pollut Bull. 62, 2588-

2597. https://doi.org/10.1016/j.marpolbul.2011.09.025

15. Gregory MR (1996) Plastic 'scrubbers' in hand cleansers: a further (and minor) source for marine pollution identified. Mar Pollut Bull. 32, 867-871. https://doi.org/10.1016/S0025-326X(96)00047-1

16. Lippiatt S, Opfer S, Arthur C (2013) Marine Debris Monitoring and Assessment. NOAA Technical Memorandum NOS-OR\&R-46.

17. Alkalay R, Pasternak G, Zask A (2007) Clean-coast index - A new approach for beach cleanliness assessment. Ocean Coast Manag. 50 (5-6), 352-362.

https://doi:10.1016/j.ocecoaman.2006.10.002

18. Okuku EO, Kiteresi L, Owato G, Otieno K, Omire J, Kombo MM, Mwalugha C, Mbuche M, Gwada B, Wanjeri V, Nelson A, Chepkemboi P, Achieng Q, Ndwiga J (2021) Temporal trends of marine litter in a tropical recreational beach: A case study of Mkomani beach, Kenya. Mar Pollut Bull. 167 (2021) 112273. https://doi.org/10.1016/j.marpolbul.2021.112273

19. Loizia P, Voukkali I, Chatziparaskeva G, Navarro-Pedreno J, Zorpas AA (2021) Measuring the Level of Environmental Performance on Coastal Environment before and during COVID-19 Pandemic. A Case Study from Cyprus. Sustainability. 13, 2485. https://doi.org/10.3390/su13052485

20. Tewelde Y, Teklemariam Y, Estifanos K (2021) Baseline of beached marine debris in three sites, Red sea - Eritrea. International Journal of Scientific \& Engineering Research. 12 (2), 292 - 308.

21. Veerasingam S, Al-Khayat JA, Aboobacker VM, Hamza S, Vethamony P (2020) Sources, spatial distribution and characteristics of marine litter along the west coast of Qatar. Mar Pollut Bull. 159, 111478. https://doi:10.1016/j.marpolbul.2020.111478

22. Ibrahim EAA, Rahim Osman NA, Eisa OAM (2020) Status of the Beach Litter in the UNESCO World Heritage Site of Dungonab and Mukkawar Island Marine National Park in Sudan, Red Sea. Int J Ecol. 1-8. https://doi:10.1155/2020/6904745 
23. Panayotova MD, Bekova RI, Stefanova KB, Todorova VR, Gumus MR, Slabakova VH, Prodanov BK, Mihova SH (2020) Seasonal Composition and Density of Marine Litter on Asparuhovo Beach, Varna, Bulgaria. Ecologia Balkanica. 3, 85-94.

24. Paler MKO, Malenab MCT, Maralit JR, Nacorda HM (2019) Plastic waste occurrence on a beach off southwestern Luzon, Philippines. Mar Pollut Bull. 141, 416-

419. https://doi:10.1016/j.marpolbul.2019.02.006

25. Giovacchini A, Merlino S, Locritani M, Stroobant M (2018) Spatial distribution of marine litter along Italian coastal areas in the Pelagos sanctuary (Ligurian Sea - NW Mediterranean Sea): A focus on natural and urban beaches. Mar Pollut Bull. 130, 140-152.

https://doi:10.1016/j.marpolbul.2018.02.042

26. Silva MLD, Castro RO, Sales AS, Araujo FVD (2018) Marine debris on beaches of Arraial do Cabo, RJ, Brazil: An important coastal tourist destination. Mar Pollut Bull. 130, 153-158. https://doi:10.1016/j.marpolbul.2018.03.026

27. Portman ME, Brennan RE (2017) Marine litter from beach-based sources: Case study of an Eastern Mediterranean coastal town. Waste Manag. 69, 535-544.

https://doi:10.1016/j.wasman.2017.07.040

28. Fernandino, G., Elliff, I.C., Silva, R.I., Brito, T.S.A., Bittencourt, C.S.P., 2016. Plastic fragments as a major component of marine litter: a case study in Salvador, Bahia, Brazil. Journal of Integrated Coastal Zone Management.16 (3) 281-287. https://doi: 10.5894/rgci649

29. Laglbauer BJL, Franco-Santos RM, Andreu-Cazenave M, Brunelli L, Papadatou M, Palatinus A, Deprez T (2014) Macrodebris and microplastics from beaches in Slovenia. Mar Pollut Bull. 89 (1-2), 356-366. https://doi:10.1016/j.marpolbul.2014.09.036

30. Karthikeyan P, Joseph A, Subagunasekar M (2021) Heavy metal pollutants and their spatial distribution in surface sediments from Thondi coast, Palk Bay, South India. Environ Sci Eur. 33, 63; 120. https://doi.org/10.1186/s12302-021-00501-2

31. Directive SF (2013) Guidance on Monitoring of Marine Litter in European Seas.

32. Chambault P, Vandeperre F, Machete M, Lagoa JC, Pham CK (2018) Distribution and composition of floating macro litter off the Azores archipelago and Madeira (NE Atlantic) using opportunistic surveys. Mar Environ Res. https://doi:10.1016/j.marenvres.2018.09.015

33. Galgani F, Hanke G, Maes T (2015) Global distribution, composition and abundance of marine litter. In: Bergman M, Gutow L, Klages M (Eds.), Marine Anthropoegenic Litter. Springer, Berlin, pp. 29-56. https://doi.org/10.1007/978-3-319-16510-3_2

34. Hardesty BD, Lawson T, Van Der Velde T, Lansdell M, Wilcox C (2016) Estimating quantities and sources of marine debris at a continental scale. Front Ecol Environ. 15(1), 18-

25. https://doi:10.1002/fee.1447

35. Ribic CA, Sheavly SB, Klavitter J (2012) Baseline for beached marine debris on Sand Island, Midway Atoll. Mar Pollut Bull. 64(8), 1726-1729. https://doi:10.1016/j.marpolbul.2012.04.001 
36. Tudor DT, Williams A (2004) Development of a "Matrix Scoring Technique" to determine litter sources at a Bristol Channel beach. J Coast Conserv. 10(1), 119. https://doi:10.1652/1400-0350

37. Veiga JM, Fleet D, Kinsey S, Nilsson P, Vlachogianni T, Werner S, Galgani F, Thompson RC, Dagevos J, Gago J, Sobral P, Cronin R (2016) Identification of sources of marine litter. In: MSFD GES TG Marine Litter Thematic Report, JRC Technical Report.

\section{Tables}

Table 1 Values, grades and visual assessment of the CCI (Alkalay et al., 2007)

\begin{tabular}{lll}
\hline Value & \multicolumn{1}{c}{ Grade } & \multicolumn{1}{c}{ Visual assessment } \\
\hline $0-2$ & Very clean & No debris is seen \\
$2-5$ & Clean & No debris is seen over a large area \\
$5-10$ & Moderate & A few pieces of debris can be detected \\
$10-20$ & Dirty & A lot of debris on the shore \\
$20+$ & Extremely dirty & Most of the beach is covered with plastic \\
\hline
\end{tabular}

Table 2 Marine debris (area $\left(\mathrm{m}^{2}\right)$, density of the debris $\left(\mathrm{Items} / \mathrm{m}^{2}\right)$, and Clean - Coast Index (CCI), and grade in Thondi coast

\begin{tabular}{ccccll}
\hline Locations & Debris count & Area $\left(\mathrm{m}^{2}\right)$ & Density & CCI & Grade \\
\hline L.1 & 124 & 400 & 0.31 & 6.2 & Moderate \\
L.2 & 153 & 400 & 0.38 & 7.65 & Moderate \\
L.3 & 176 & 400 & 0.44 & 8.8 & Moderate \\
\hline L.4 & 85 & 400 & 0.21 & 4.25 & Clean \\
L.5 & 132 & 400 & 0.33 & 6.6 & Moderate \\
\hline L.6 & 407 & 400 & 1.02 & 20.4 & Extremely Dirty \\
\hline L. & 113 & 400 & 0.28 & 5.65 & Moderate \\
\hline L. 8 & 93 & 400 & 0.23 & 4.65 & Clean \\
\hline L.9 & 129 & 400 & 0.32 & 6.45 & Moderate \\
\hline L.10 & 224 & 400 & 0.56 & 11.2 & Dirty \\
\hline
\end{tabular}

\section{Figures}




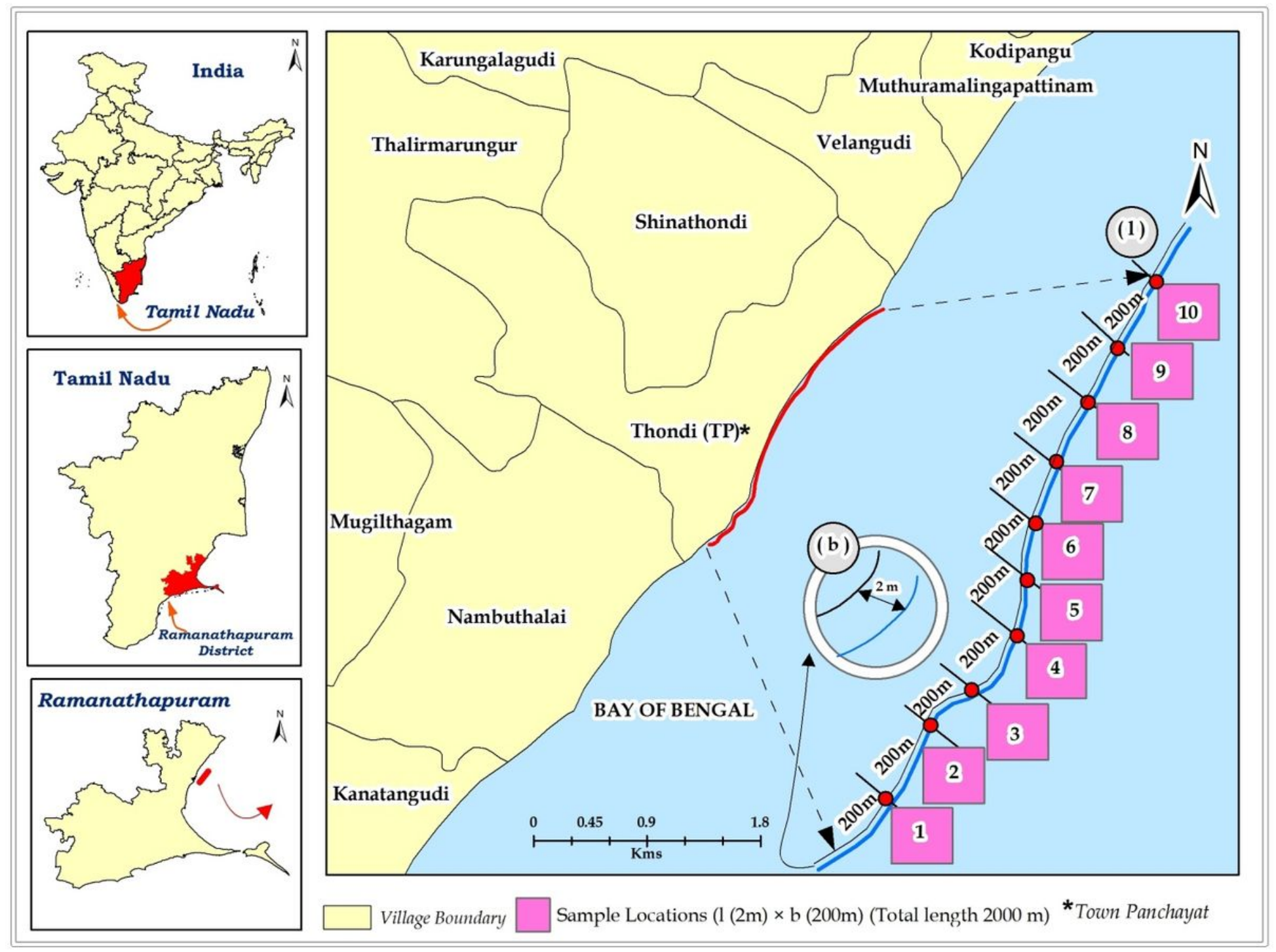

Figure 1

Map of study area and samples collections. 

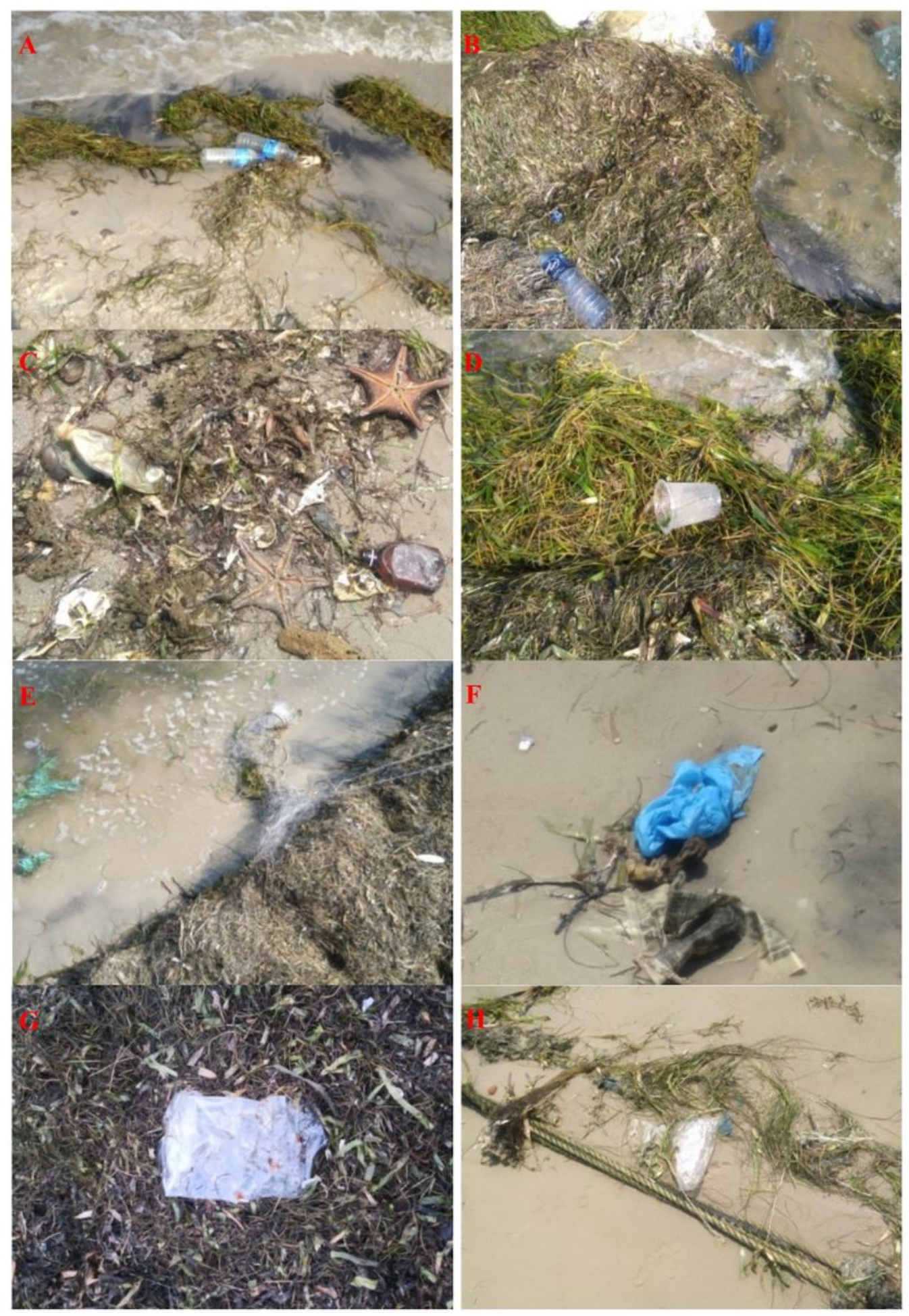

\section{Figure 2}

Plastic debris observed on the coast of Thondi: A-C. Plastic bottles, D. Plastic cup E. Fishing nets, and FH. Plastic bags. 


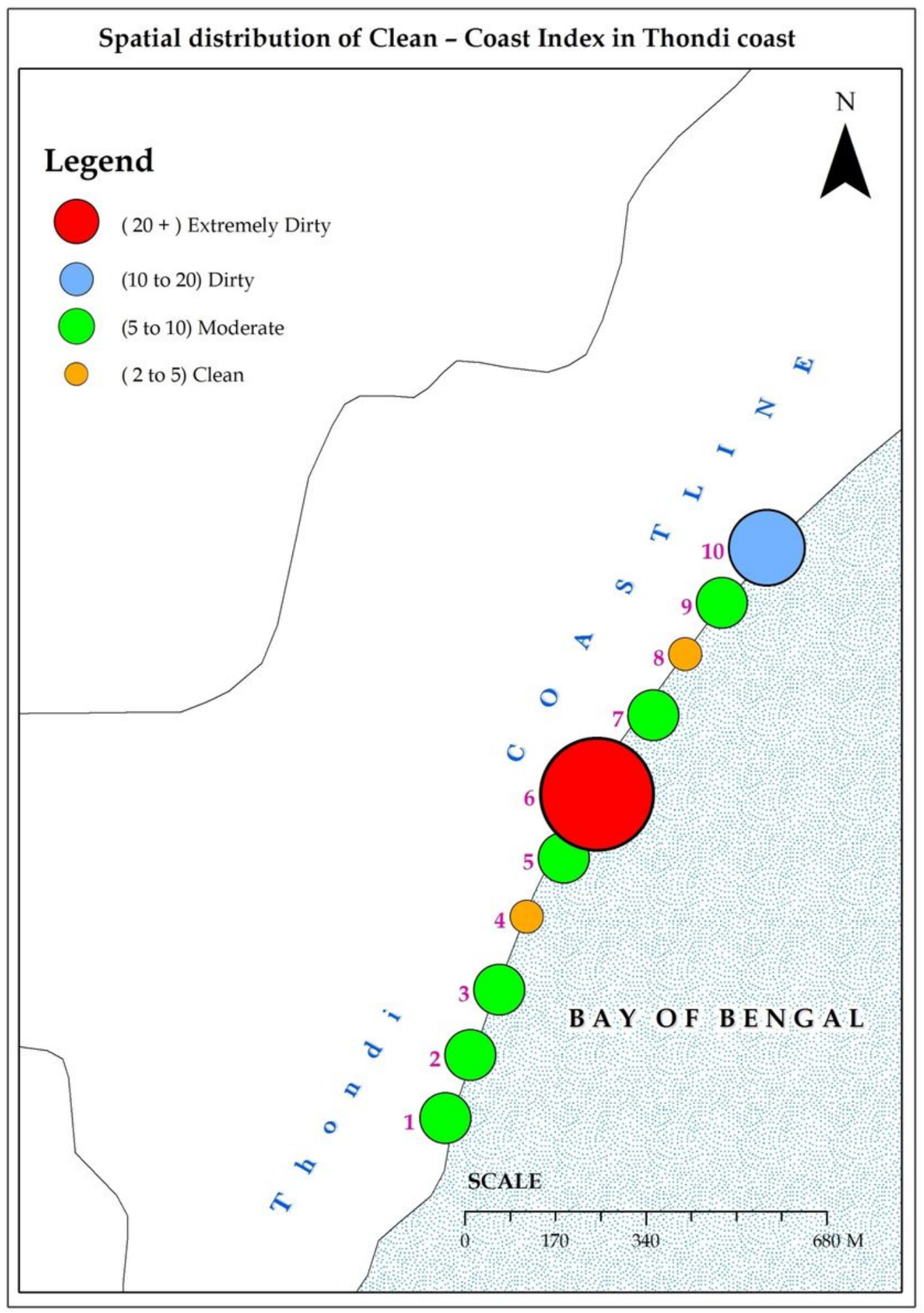

Figure 3

Pollution status of Thondi coast according to the Clean - Coast Index (CCI)

\section{Supplementary Files}

This is a list of supplementary files associated with this preprint. Click to download. 
- Coveringletter.docx

Page 16/16 